\title{
Is oestrogen receptor- $\beta$ a predictor of endocrine therapy responsiveness in human breast cancer?
}

\author{
Leigh C Murphy ${ }^{1}$ and Peter H Watson ${ }^{2}$
}

\begin{abstract}
Manitoba Institute of Cell Biology, Departments of ${ }^{1}$ Biochemistry and Medical Genetics and ${ }^{2}$ Pathology, University of Manitoba, and Cancer Care Manitoba Winnipeg, Canada R3E OV9

(Requests for offprints should be addressed to L C Murphy; Email: Icmurph@cc.umanitoba.ca)
\end{abstract}

\begin{abstract}
The role of oestrogen receptor (ER) $\beta$ in human breast cancer remains unclear. However, it is now apparent that when considering ER $\beta$ in human breast cancer it is important to recognise two ER $\beta$ expressing groups, one in which ER $\beta$ is co-expressed with ER $\alpha$ and the other where ER $\beta$ is expressed alone. Emerging data support different functions between ER $\beta$ when it is expressed alone and when it is co-expressed with $E R \alpha$. With regard to the latter group $(E R \alpha+/ E R \beta+)$, there are now 9 out of 10 retrospective clinical outcome studies published, that support the hypothesis that increased expression of ER $\beta$ is associated with increased likelihood of response to endocrine therapy. The data strongly support undertaking prospective studies to determine if the addition of $E R \beta$ to $E R \alpha$ is clinically beneficial and whether to include both $E R \beta$ and $E R \alpha$ when establishing clinically relevant cut-offs for defining ER status.
\end{abstract}

Endocrine-Related Cancer (2006) 13 327-334

\section{Introduction}

Oestrogens are pivotal in the growth and development of both normal and neoplastic mammary tissues (Kelsey 1993), and mediate most of their action via ligand-dependent transcription factors called oestrogen receptors (ER). In pathological lesions associated with increased risk of breast cancer, there is a significant increase in the proportion of cells that express ER (Khan et al. 2002, Shaaban et al. 2002). Also ER expression is present in approximately $70 \%$ of invasive breast cancers. Importantly, ER is the primary target for both chemoprevention and endocrine therapy of breast cancer (Ali \& Coombes 2002). The ER status of breast tumours (determined as a binary factor of or + ) provides prognostic information but more importantly is a predictor of response to endocrine therapy (Ali \& Coombes 2002). The former role may relate to an indirect association between ER expression and a distinct cell 'circuitry' associated with a 'well differentiated' morphological appearance. The second relates to the central role of ER within the oestrogen signaling pathway so that
ER inactivation inhibits oestrogen signaling and the proliferative action of oestrogen on ER+ human breast cancer cells (Lippman \& Bolan 1975). This is the rationale for measuring ER and progesterone receptor (PR), a down-stream marker of functional ER signalling (Horwitz et al. 1978), routinely in breast cancer biopsies. In addition, ER - status is associated with specific subsets of in situ and invasive breast cancer that display aggressive biological behaviour (Holland et al. 1997, Lapidus et al. 1998). Therefore, despite the fact that ER status is already an important biomarker in breast cancer, (Ali \& Coombes 2002), it is now appreciated to be far more complex. There are now two known ERs - ER $\alpha$ and ER $\beta$ (Ali \& Coombes 2002) which has led to a re-evaluation of oestrogen action in target tissues such as breast tumours.

With respect to human breast cancer, the previous and current assays used for determining ER status in most cases generally detect only ER $\alpha$ (see ER assays below) but the newer ER $\beta$ is clearly expressed in both normal and neoplastic human breast tissue (Leygue et al. 1998, Jarvinen et al. 2000), although 
its role in either is unknown. In animal studies, while $\mathrm{ER} \alpha$ has been shown to be essential for normal mammary gland development, ER $\beta$ effects are more subtle, with roles in terminal differentiation (Forster et al. 2002) and modulation of ER $\alpha$ activity being described (Hall \& McDonnell 1999, Weihua et al. 2000, Peng et al. 2003). However, $\mathrm{ER} \beta$ effects on mammary tumourigenesis in animal models have not been reported. In this review, we discuss data concerning ER $\beta$ expression in human breast cancer in vivo and its relationship to clinical outcome in order to gain insight into the putative function(s) of ER $\beta$ in human breast cancer. A review has recently been published which also deals with the clinical significance of $\operatorname{ER} \beta$ and its isoforms in breast cancer (Saji et al. 2005). The current review builds on this by incorporating additional studies and by focusing specifically on ER $\beta$, the relationship between clinical ER assays and endocrine therapy outcome, and the likelihood that $\mathrm{ER} \beta$ in addition to $\mathrm{ER} \alpha$ may be a clinically useful biomarker of treatment responsiveness in breast cancer.

\section{ER assays}

Traditionally, whole tissue extract/cytosol-based radioligand-binding assays (LBA, dextran-coated charcoal assay, DCC) were used to determine ER and PR in biopsies. In these assays ER is measured in $\mathrm{fmol} / \mathrm{mg}$ protein and cut-offs of between $3-10 \mathrm{fmol} / \mathrm{mg}$ protein (based on clinical response data) (Osborne 1998) are used to define ER status as negative or positive. But, absolute levels of ER also provide relevant predictive information, increasing ER levels are associated with the increased likelihood of response to endocrine therapies (Osborne 1998). Since ER $\alpha$ and ER $\beta$ bind radiolabelled oestradiol-17 $\beta$ similarly, such assays do not discriminate between ER $\alpha$ and ER $\beta$. In most cases, the level of ER $\alpha$ RNA greatly exceeds (10-100 times) ER $\beta$ RNA in breast tumours (Ariazi et al. 2002) leading to the assumption that $E R \alpha$ protein levels greatly exceed ER $\beta$ protein levels. In general, ER $\alpha$ is up-regulated and $\operatorname{ER} \beta$ is down-regulated in breast tumours, it is not surprising that LBAs correlate well with ER $\alpha$ RNA levels (Dotzlaw et al. 1990). It is generally thought that LBAs most often detect ER $\alpha$ with little interference from ER $\beta$ (Brouillet et al. 2001). However, exceptions may occur (Saji et al. $2002 a, b$ ). Newer methods using specific monoclonal antibodies raised against $\operatorname{ER} \alpha$ allow detection of
ER, both in whole tissue/cytosolic extracts (ELISA) and in tissue sections using immunohistochemistry (IHC). These antibody-based assays generally correlate well with LBA in breast tumour extracts (Osborne 1998). The biochemical assays (DCC and EIA) as well as IHC methods, while having specific advantages and disadvantages, produce information that is useful for therapeutic decision making. DCC assays measure ER level and function (ligand-binding ability), but relatively large amounts of biopsy tissue are required, a problem with respect to the overall trend to the decreased size of breast tumours over the last few years due to earlier detection technologies. Also, this assay does not account for tumour heterogeneity and therefore contribution from different elements other than invasive tumour cells, such as normal and/or preneoplastic breast cells, in addition to vascular and immune cells are unknown. In contrast, IHC uses $5 \mu \mathrm{m}$ sections of a biopsy, can localize positive cells and their relative proportion in the tumour. However, quantification is imprecise and the information derived is fundamentally different from the DCC assay. In fact, we have previously shown that ER $\alpha$ status measured by IHC can be different with different antibodies and that the discrepancies can be correlated in some cases with the expression of $\mathrm{ER} \alpha$ variant mRNA that might encode proteins recognised by only a subset of $\mathrm{ER} \alpha$ antibodies (Huang et al. 1997, 1999). Nevertheless, with good correlation between the assays established, and sensitive ER $\alpha$ antibodies available, $E R \alpha$ is generally measured by current assays and $\mathrm{ER} \alpha$ is correlated with prognosis and treatment response (Harvey et al. 1999, Osborne 1998) in breast tumours. However, with increasing evidence of a role of ER $\beta$ in breast cancer (see below), we would argue that ER status should now include both ER $\alpha$ and ER $\beta$.

\section{Assessment of ER- $\beta$ expression}

In contrast to $E R \alpha$, published data suggest that $E R \beta$ expression declines during breast tumourigenesis (Leygue et al. 1998, Roger et al. 2001). This general downregulation of ER $\beta$ in breast tumours compared with normal breast tissue, suggests a role for $E R \beta$ as a tumour suppressor (Skliris et al. 2003). Nevertheless, ER $\beta$ expression in breast tumours varies widely (Dotzlaw et al. 1999, Jarvinen et al. 2000) and attempts to correlate ER $\beta$ with various biomarkers has resulted in varied, often contradictory conclusions (Speirs 2002). In 

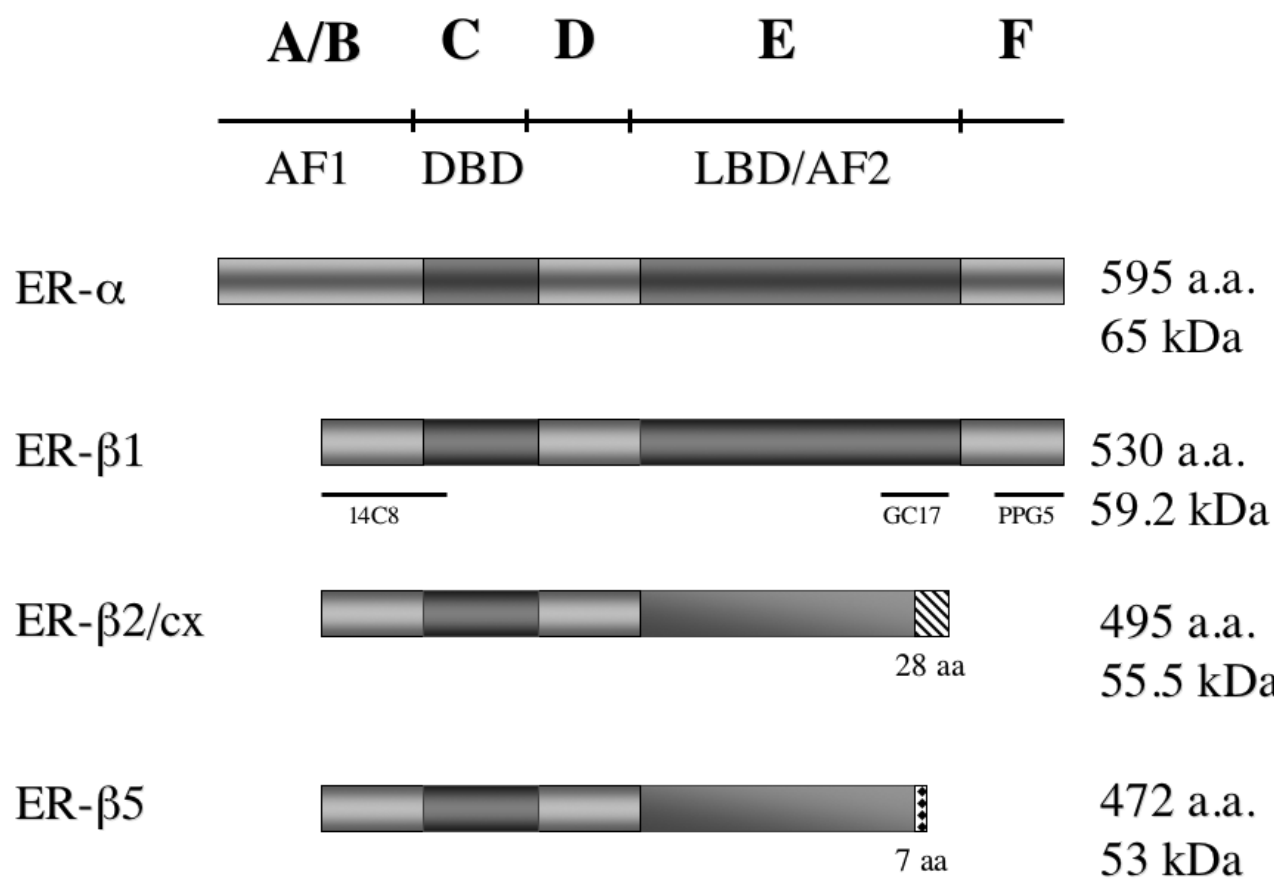

Figure 1 Schematic representation of human $E R \alpha$ and $\beta$ isoform proteins. Human ER $\beta 1$ is in the full-length ligand binding form, and $\mathrm{hER} \beta 2 / \mathrm{cx}$ and $\mathrm{hER} \beta 5$ are two commonly occurring C-terminally truncated non-ligand binding variants. $14 \mathrm{C} 8$ was made to peptide consisting of amino acids 1-153 of long form of ER $\beta$; GC17 to amino acids 449-465; PPG5 to amino acids 512-530.

part, this is due to how ER $\beta$ expression was determined (RNA or protein) and/or which antibody was used (Skliris et al. 2002). The latter is important since variant non-ligand binding ER $\beta$ proteins have been detected in breast tissues (Fuqua et al. 1999, Saji et al. 2002b) and their function may be distinct from that of the full-length ligand-binding ER $\beta 1$ protein (Fig. 1) (Saji et al. 2002a, Peng et al. 2003). Therefore depending on the antibody used, fulllength ER $\beta$ only or total (full-length plus variants) $\mathrm{ER} \beta$ is determined. Also, assay protocols and criteria for scoring ER $\beta$ status $(+$ or - ) varies among studies (Jarvinen et al. 2000, Mann et al. 2001, Fuqua et al. 2003, Carder et al. 2005), and there are no prospectively obtained clinically relevant cut-off values.

Several ER $\beta$ specific antibodies have now been used for IHC to detect ER $\beta$-like proteins. Skliris et al. (2002) have previously compared various antibodies for their usefulness in IHC. They found that for formalin-fixed paraffin embedded tissues Ab288/14C8 (Fuqua et al. 1999) and MCA1974S/ PPG5/10 (Saunders et al. 2002; see Fig. 1 for regions of ER $\beta$ used to generate antibodies) both commercially available from Abcam and Serotec, respectively, gave the most superior nuclear staining. Both these antibodies have been validated for their specificity (Saunders et al. 2002, Skliris et al. 2002, G Weitsman, G Skliris, K Ung, B Peng, M Younes, P H Watson \& L C Murphy, unpublished observations). However, other antibodies were found more reliable for frozen tissue IHC or for Western blotting, immunoprecipitation or FACS analysis (Skliris et al. 2002, G Weitsman, G Skliris, K Ung, B Peng, M Younes, P H Watson \& L C Murphy, unpublished observations). This previous study did not include an evaluation of the rabbit polyclonal GC17/385P ER $\beta$ antibody (Biogenex, USA; see Fig. 1), which has also been rigorously validated for its specificity and usefulness in formalin-fixed paraffin-embedded tissue sections (Leav et al. 2001). We routinely use 14C8 and GC17 ER $\beta$ antibodies for the specific immunohistochemical evaluation of ER $\beta$ in human breast tumour sections and tissue microarrays using tumours processed by and stored in the Manitoba Breast Tumour Bank (Watson et al. 1996, Murphy et al. 2002, Skliris et al. 2005, G Weitsman, G Skliris, K Ung, B Peng, M Younes, P H Watson \& L C Murphy, unpublished observations). However the equally important issues are the differences in protocols and procedures that are used for immunohistochemical analysis of ER $\beta$ as underscored by Speirs et al. (Carder et al. 2005). 
Table 1 Summary of retrospective studies of ER $\beta$ protein expression and clinical outcome in breast cancer

\begin{tabular}{|c|c|c|c|c|}
\hline Author/Reference & $\begin{array}{l}\text { Number of } \\
\text { patients in study }\end{array}$ & $\begin{array}{l}\text { ER } \beta \text { detection } \\
\text { (antibody) }\end{array}$ & Treatment & Clinical outcome ( $P$ value) \\
\hline Mann et al. (2001) & 118 & $\mathrm{IHC}(\mathrm{N})$ & Tam & $\begin{array}{l}\text { ER } \beta+\text { associated with increased OS } \\
\quad(0.0077)\end{array}$ \\
\hline Murphy et al. (2002) & 27 & $\mathrm{IHC}(\mathrm{N})$ & Tam & $\begin{array}{l}\text { Higher ER } \beta \text { associated with no } \\
\text { disease progression }(0.046)\end{array}$ \\
\hline Omoto et al. (2001) & 88 & $\mathrm{IHC}(\mathrm{C})$ & Tam \& Chemo & $\begin{array}{l}\text { ER } \beta+\text { associated with increased DFS } \\
\quad(0.032)\end{array}$ \\
\hline Fleming et al. (2004) & 52 & $\mathrm{IHC}(\mathrm{C})$ & Tam & $\begin{array}{l}\text { ER } \beta+\text { associated with no relapse } \\
\text { within } 5 \text { years }(<0.05)\end{array}$ \\
\hline Esslimani-Sahla et al. (2004) & 50 & $\mathrm{IHC}(\mathrm{N})$ & Tam & $\begin{array}{l}\text { Higher ER } \beta \text { associated with no } \\
\text { relapse within } 5 \text { years }(0.004)\end{array}$ \\
\hline Hopp et al. (2004) & 186 & $\mathrm{IHC}(\mathrm{N})$ & Tam & $\begin{array}{l}\text { Higher ER } \beta \text { associated with improved } \\
\text { DFS (0.0063) and OS (0.03) }\end{array}$ \\
\hline Iwase et al. (2003) & 77 & $\mathrm{IHC}(\mathrm{C})$ & $\begin{array}{l}\text { Tam or other } \\
\text { endocrine therapies }\end{array}$ & $\begin{array}{l}\text { ER } \beta+\text { show better response to } \\
\text { endocrine therapy }(0.088)\end{array}$ \\
\hline O’Neill et al. (2004) & 138 & $\mathrm{IHC}(\mathrm{C})$ & Tam & ER $\beta+$ show worse OS (0.09) \\
\hline Myers et al. (2004) & 150 & $\mathrm{IHC}(\mathrm{C})$ & Tam \& Chemo & $\begin{array}{l}\text { ER } \beta+\text { associated with increased DFS } \\
\quad(0.0008)\end{array}$ \\
\hline Nakopoulou et al. (2004) & 181 & $\mathrm{IHC}(\mathrm{C})$ & Tam \& Chemo & $\begin{array}{l}\text { ER } \beta+\text { associated with increased DFS } \\
(0.0002) \text { and OS }(0.0002)\end{array}$ \\
\hline
\end{tabular}

$\mathrm{N}$, antibody detects an $\mathrm{N}$-terminal ER $\beta$ epitope; $\mathrm{C}$, antibody detects a specific $\mathrm{C}$-terminal epitope of the full-length ligand binding ER $\beta 1$ protein; Tam, tamoxifen; chemo, chemotherapy; IHC immunohistochemistry; WB, western blot. DFS, disease free survival; OS, overall survival.

\section{ER- $\beta$ expression and its potential role as a predictor of treatment response in breast cancer}

The marked discrepancy between conclusions drawn from studies of ER $\beta$ measured by RNA compared with those where ER $\beta$ was measured at the protein level has been underscored by Saji et al. (2005). As noted by Saji et al. (2005) no clear explanation exists. However such discrepancies may be due to the fact that when RNA is measured in extracts from either breast tissue sections or chunks of tissue, the RNA represents a pool of all the different cell types present in the biopsy e.g. stromal vascular cells, infiltrating lymphocytes, most of which will also express ER $\beta$, and normal, preinvasive and invasive epithelial cells, where the extent of contaminating normal epithelium may have a significant influence.(Roger et al. 2001, Murphy et al. 2002, Skliris et al. 2002). It is also possible that some factors involved in changing the sensitivity of IHC to some antigens are not relevant to ER $\beta$ RNA assays (McCabe et al. 2005). However, most determinants of ER $\beta$ protein expression in breast tumours are done using IHC which allows expression in invasive breast cancer cells to be assessed independently of other cell types. Therefore for the purposes of the following discussion only those studies, where ER $\beta$ protein was determined
(IHC or in one study by western blotting), are considered.

A common, but not universal finding, is that ER $\beta$ expression correlates with ER $\alpha$ and PR expression (Jarvinen et al. 2000, Murphy et al. 2002, Omoto et al. 2002), which are good prognostic and treatment response biomarkers. While the role of ER $\beta$ in breast cancer is unclear, one important currently emerging hypothesis is that increased expression of ER $\beta$ is associated with increased likelihood of response to endocrine therapy.

As of January 2006 there are ten retrospective studies that have assessed ER $\beta$ expression in relation to clinical outcome associated with endocrine therapy in breast cancer (Table 1). Seven of these assessed ER $\beta$ expression in relation to responsiveness to tamoxifen therapy or other endocrine therapies (Mann et al. 2001, Murphy et al. 2002, Iwase et al. 2003, Esslimani-Sahla et al. 2004, Fleming et al. 2004, Hopp et al. 2004, O'Neill et al. 2004). Three assessed ER $\beta$ expression with respect to disease free survival in patients who were treated with chemotherapy and tamoxifen (Omoto et al. 2001, Myers et al. 2004, Nakopoulou et al. 2004). No formal meta-analysis has been done, but in the first group of studies, five out of seven found that increased levels of ER $\beta$ were associated with a better disease outcome and consistent with the breast tumour being tamoxifen sensitive (Mann 
et al. 2001, Murphy et al. 2002, Esslimani-Sahla et al. 2004, Fleming et al. 2004, Hopp et al. 2004). The patient/tumour characteristics are of course mixed but the total combined patient number in these five 'positive' studies is 433 , compared with 138 patients in the one 'negative' study, where no significant difference was found although there was a trend to worse outcome in those patients whose tumours had higher ER $\beta$ expression ( $P=0.09$; O'Neill et al. 2004) and 77 patients in the other 'not significant' study, where a trend toward higher ER $\beta$ was being associated with better response to tamoxifen $(P=0.088$; Iwase et al. 2003) was found. There are also three studies (Omoto et al. 2001, Myers et al. 2004, Nakopoulou et al. 2004) in which ER $\beta$ expression in primary tumours was compared with disease free survival but where the patient's treatment included chemotherapy plus tamoxifen. All these studies show a significant association of higher ER $\beta$ expression and better disease free survival, with total accumulated patient numbers of 419 . Three of the above studies (Mann et al. 2001, Hopp et al. 2004, Nakopoulou et al. 2004) also show a significant association of higher ER $\beta$ expression and overall survival. So there are nine studies published where the conclusion was made that ER $\beta$ expression in breast tumours is associated with better disease outcome of the patients $(n=929)$ compared with one study where $\operatorname{ER} \beta$ expression is associated with worse disease outcome $(n=138)$.

However, when considering ER $\beta$ expression in breast cancers in vivo there are two groups, one where $E R \beta$ is coexpressed with $E R \alpha(E R \beta+/$ $\mathrm{ER} \alpha+)$ and the other where $\mathrm{ER} \beta$ is expressed alone $(\mathrm{ER} \beta+/ \mathrm{ER} \alpha-)$. The first group, $(\mathrm{ER} \beta+/$ $\mathrm{ER} \alpha+$ ), comprises $\sim 59 \%$ of primary human breast cancers (Murphy et al. 2003, Saji et al. 2005), while the ER $\beta$ alone expressing group comprises $\sim 17 \%$ of breast cancers (Murphy et al. 2003, Saji et al. 2005). Generally it is only patients whose tumours are ER + that are treated with tamoxifen (or other endocrine therapies) and ER+ status is determined only by $E R \alpha$ (specific ER $\alpha$ antibodies are used in current IHC clinical assays, as discussed above). Therefore the majority of tumours being assessed in the above studies are those co-expressing ER $\beta$ with $E R \alpha$. These data support the hypothesis that assessment of ER $\beta$ together with $E R \alpha$ is a better predictor of endocrine responsiveness than ER $\alpha$ alone. In addition, since some studies suggest that ER $\beta$ correlates with and also regulates PR expression together with ER $\alpha$ (Jarvinen et al. 2000, Omoto et al. 2001, Murphy et al. 2002, 2005) it may be that $\mathrm{ER} \beta$ and $\mathrm{ER} \alpha$ are better biomarkers than ER $\alpha$ and PR, or alternatively the three biomarkers in combination may be the most precise predictors of endocrine responsiveness. However since the clinical studies discussed above were small, retrospective, used different protocols, antibodies and cut-off values to determine positive or negative ER $\beta$ status, a definitive conclusion regarding the addition of $E R \beta$ to $E R \alpha$ as a better predictor of endocrine response than $E R \alpha$ alone cannot be made and there is insufficient evidence to enable incorporation of a promising ER $\beta$ assay into the clinic.

The second group of ER $\beta$ expressing tumours $(\mathrm{ER} \beta+/ \mathrm{ER} \alpha-)$ would traditionally be classified as ER-. ER - tumours are more aggressive and less than $10 \%$ respond to endocrine therapies (Osborne 1998). However, now it appears that greater than $50 \%$ of all tumours previously classified as ERexpress ER $\beta$ (Murphy et al. 2003). It has been suggested that some of the so called ER - tumours where the patient responded to endocrine therapy were due to false negative assays for technical reasons (Muschenheim et al. 1978, Clarke et al. 2001), or ER-independent mechanisms associated with tamoxifen action (Clarke et al. 2001), however, a role of ER $\beta$ in this group of tumours is now another possibility. ER $\beta+/ E R \alpha-$ tumours generally have received very little attention, however, there are three studies (Jensen et al. 2001, O'Neill et al. 2004) including our own unpublished study (Skliris et al. 2005) with a total combined 389 cases where ER $\beta+$ alone expressing tumours have been investigated. All three studies identified a significant association of ER $\beta$ expression with Ki67, a marker of proliferation, and one study also identified a significant association of ER $\beta$ with cyclin A expression (Jensen et al. 2001). Such data suggest that the role of ER $\beta$ in the absence of ER $\alpha$ expression in breast cancer is different to that when ER $\beta$ is co-expressed with ER $\alpha$. Furthermore a different function of ER $\beta$ when expressed alone is also supported mechanistically, since when $\operatorname{ER} \beta$ is co-expressed with $\mathrm{ER} \alpha$ they will form heterodimers (Cowley et al. 1997) preferentially. Recent fluorescence resonance energy transfer (FRET) analyses showed formation of both ER $\alpha$ and ER $\beta$ homoand hetero-dimers in situ in living cells in culture (Bai \& Giguere 2003). This activity may underlie observations that ER $\beta$ often but not always, has a negative modulatory effect on $\mathrm{ER} \alpha$ when coexpressed (Ogawa et al. 1998, Hall \& McDonnell 1999, Peng et al. 2003). In contrast, when ER $\beta$ is expressed alone it will homodimerize. Distinct as 
well as overlapping activity, as assessed by determining gene expression profiles using DNA microarray analyses, has been demonstrated for each type of ER homodimer and $\mathrm{ER} \beta / \mathrm{ER} \alpha$ heterodimers in osteosarcoma cell line models, engineered to express ER $\beta$ alone, ER $\alpha$ alone, or both ER $\beta$ and $\mathrm{ER} \alpha$ (Monroe et al. 2005). An implication of these data is the possibility that targeting ER $\beta$ pathway(s) in the $E R \alpha-$ but $E R \beta+$ group of patients may be a treatment option for these patients who generally have few options other than aggressive chemotherapies. However, further studies are required with respect to this issue.

\section{Conclusion}

When considering ER $\beta$ in human breast cancer it is important to recognise two ER $\beta$ expression cohorts since there are emerging data supporting differential function of $E R \beta$ when it is expressed alone compared with when it is co-expressed with ER $\alpha$. While the differential role of ER $\beta$ in the absence of $\mathrm{ER} \alpha$ is intriguing and deserves continued study, the retrospectively collected data summarised above investigating the relationship between ER $\beta$ when coexpressed with ER $\alpha$ and clinical outcome, strongly support the undertaking of definitive prospective studies to determine if the addition of $E R \beta$ to $E R \alpha$ is clinically beneficial, and if so to establish clinically relevant cut-off values for defining ER status to include both ER $\beta$ and ER $\alpha$. Such studies require standardized approaches (Carder et al. 2005) reagents, protocols and cutpoints (McCabe et al. 2005) and equipment routinely available to a clinical pathology laboratory to enable incorporation of a promising ER $\beta$ assay into the clinic.

\section{Acknowledgements}

The research is supported by Canadian Institutes of Health Research (CIHR), Canadian Breast Cancer Research Alliance (CBCRA), and USA Department of Defense-Breast Cancer Research Program (DOD-BCRP) operating grants. We acknowledge the strong support of the CancerCare Manitoba Foundation for our facilities at MICB. The authors declare that there is no conflict of interest that would prejudice the impartiality of this scientific work.

\section{References}

Ali S \& Coombes R 2002 Endocrine-responsive breast cancer and strategies for combating resistance. Nature Reviews $\mathbf{2}$ 101-112.
Ariazi E, Clark G \& Mertz J 2002 Estrogen-related receptor alpha and estrogen-related receptor gamma associate with unfavorable and favorable biomarkers respectively in human breast cancer. Cancer Research 62 6510-6518.

Bai Y \& Giguere V 2003 Isoform-selective interactions between estrogen receptors and steroid receptor coactivators promoted by estradiol and erbB-2 signaling in living cells. Molecular Endocrinology 17 589-599.

Brouillet J, Dujardin M, Chalbos D, Rey J, Grenier J, Lamy P, Maudelonde T \& Pujol P 2001 Analysis of the potential contribution of estrogen receptor (ER) $\beta$ in ER cytosolic assay of breast cancer. International Journal of Cancer $\mathbf{9 5}$ 205-208.

Carder P, Murphy C, Dervan P, Kennedy M, McCann A, Saunders P, Shaaban A, Foster C, Witton C, Bartlett J, Walker R \& Speirs V 2005 A multi-centre investigation towards reaching a consensus on the immunohistochemical detection of ERbeta in archival formalin-fixed paraffin embedded human breast tissue. Breast Cancer Research and Treatment 92 287-293.

Clarke R, Leonessa F, Welch J \& Skaar T 2001 Cellular and molecular pharmacology of antiestrogen action and resistance. Pharmacology Reviews 53 25-71.

Cowley S, Hoare S, Mosselman S \& Parker M 1997 Estrogen receptors alpha and beta form heterodimers on DNA. Journal of Biological Chemistry 272 19858-19862.

Dotzlaw H, Miller T, Karvelas J \& Murphy L 1990 Epidermal growth factor gene expression in human breast cancer biopsy samples: relationship to estrogen and progesterone receptor gene expression. Cancer Research 50 4204-4208.

Dotzlaw H, Leygue E, Watson P \& Murphy L 1999 Estrogen receptor- $\beta$ messenger RNA expression in human breast tumor biopsies: relationship to steroid receptor status and regulation by progestins. Cancer Research 59 529-532.

Esslimani-Sahla M, Simony-Lafontaine J, Kramar A, Lavaill R, Mollevi C, Warner M, Gustafsson J.-A \& Rochefort H 2004 Estrogen receptor beta (ERbeta) level but not its ERbeta-cx variant helps to predict tamoxifen resistance in breast cancer. Clinical Cancer Research $\mathbf{1 0}$ 5769-5776.

Fleming F, Hill A, McDermott E, O'Higgins N \& Young L 2004 Differential recruitment of coregulator proteins steroid receptor coactivator-1 and silencing mediator for retinoid and thyroid receptors to the estrogen receptorestrogen response element by beta-estradiol and 4-hydroxytamoxifen in human breast cancer. Journal of Clinical Endocrinology and Metabolism 89 375-383.

Forster C, Makela S, Warri A, Kietz S, Becker D, Hultenby K, Warner M \& Gustafsson J 2002 Involvement of estrogen receptor $\beta$ in terminal differentiation of mammary gland epithelium. PNAS 99 15578-15583.

Fuqua S, Schiff R, Parra I, Friedrichs W, Su J, McKee D, Slentz-Kesler K, Moore L, Willson T \& Moore J 1999 Expression of wild-type estrogen receptor beta and variant isoforms in human breast cancer. Cancer Research 59 5425-5428. 
Fuqua S, Schiff R, Parra I, Moore J, Mohsin S, Osborne C, Clark G \& Allred D 2003 Estrogen receptor beta protein in human breast cancer: correlation with clinical tumor parameters. Cancer Research 63 2434-2439.

Hall J \& McDonnell D 1999 The estrogen receptor betaisoform (ERbeta) of the human estrogen receptor modulates ERalpha transcriptional activity and is a key regulator of the cellular response to estrogens and antiestrogens. Endocrinology 140 5566-5578.

Harvey J, Clark G, Osborne C \& Allred D 1999 Estrogen receptor status by immunohistochemistry is superior to the ligand binding assay for predicting response to adjuvant endocrine therapy in breast cancer. Journal of Clinical Oncology 17 1474-1481.

Holland P, Knox W, Potten C, Howell A, Anderson E, Baildam A \& Bundred N 1997 Assessment of hormone dependence of comedo ductal carcinoma in situ of the breast. Journal of the National Cancer Institute 89 1059-1065.

Hopp T, Weiss H, Parra I, Cui Y, Osborne C \& Fuqua S 2004 Low levels of estrogen receptor beta protein predict resistance to tamoxifen therapy in breast cancer. Clinical Cancer Research 10 7490-7499.

Horwitz K, Koseki Y \& McGuire W 1978 Estrogen control of progesterone receptor in human breast cancer: role of estradiol and antiestrogen. Endocrinology 103 1742-1751.

Huang A, Leygue E, Snell L, Murphy L \& Watson P 1997 Expression of estrogen receptor variants mRNAs and determination of estrogen status in human breast cancer. American Journal of Pathology 150 1827-1833.

Huang A, Leygue E, Dotzlaw H, Murphy L \& Watson P 1999 Estrogen receptor- $\alpha$ mRNA variants influence the determination of estrogen receptor status in human breast cancer. Breast Cancer Research Treatment 58 219-225.

Iwase H, Zhang Z, Omoto Y, Sugiura H, Yamashita H, Toyama T, Iwata H \& Kobayashi S 2003 Clinical significance of the expression of estrogen receptors alpha and beta for endocrine therapy of breast cancer. Cancer Chemotherapy and Pharmacology 52 (Suppl 1) S34-S38.

Jarvinen T, Pelto-Huikko M, Holli K \& Isola, J 2000 Estrogen receptor beta is coexpressed with ERalpha and PR and associated with nodal status grade and proliferation rate in breast cancer. American Journal of Pathology 156 29-35.

Jensen E, Cheng G, Palmieri C, Saji S, Makela S, Noorden S.v, Wahlstrom T, Warner M, Coombes R \& Gustafsson J-A 2001 Estrogen receptors and proliferation markers in primary and recurrent breast cancer. PNAS 98 15197-15202.

Kelsey J 1993 Epidemiologic Reviews: Breast Cancer. Vol. 15. Ed. HK Armenian. Johns Hopkins University School of Hygiene and Public Health Maryland USA: Baltimore.

Khan S, Yee K, Kaplan C \& JF Siddiqui 2002 Estrogen receptor alpha expression in normal human breast epithelium is consistent over time. International Journal of Cancer 102 334-337.

Lapidus R, Nass S \& Davidson N 1998 The loss of estrogen and progesterone receptor gene expression in human breast cancer. Journal of Mammary Gland, Biology and Neoplasia 3 85-94.
Leav I, Lau K.-M, Adams J, McNeal J, Taplin M-E, Wang J, Singh H \& Ho S-M 2001 Comparative studies of the estrogen receptor $\beta$ and $\alpha$ and the androgen receptor in normal human prostate glands dysplasia and in primary and metastatic carcinoma. American Journal of Pathology 159 79-92.

Leygue E, Dotzlaw H, Watson P \& Murphy L 1998 Altered estrogen receptor alpha and beta mRNA expression during human breast tumorigenesis. Cancer Research $\mathbf{5 8}$ 3197-3201.

Lippman M \& Bolan G 1975 Oestrogen responsive human breast cancer in long term tissue culture. Nature 256 592-593.

McCabe A, Dolled-Filhart M, Camp R \& Rimm D 2005 Automated quantitative analysis (AQUA) of in situ protein expression antibody concentration and prognosis. Journal of the National Cancer Institute 97 1808-1815.

Mann S, Laucirica R, Carlson N, Younes P, Ali N, Younes A, Li Y \& Younes M 2001 estrogen receptor beta expression in invasive breast cancer. Human Pathology 32 113-118.

Monroe D, Secreto F, Subramaniam M, Getz B, Khosla S \& Spelsberg T 2005 Estrogen receptor alpha and beta heterodimers exert unique effects on estrogen- and tamoxifen-dependent gene expression in human U2OS osteosarcoma cells. Molecular Endocrinology 19 1555-1568.

Murphy L, Leygue E, Niu Y, Snell L, Ho S-M \& Watson P 2002 Relationship of coregulator and estrogen receptor isoform expression to de novo tamoxifen resistance in human breast cancer. British Journal of Cancer $\mathbf{8 7}$ 1411-1416.

Murphy L, Cherlet T, Lewis A, Banu Y \& Watson P 2003 New insights into estogen receptor function in human breast cancer. Annals of Medicine 35 614-631.

Murphy L, Peng B, Lewis A, Davie J, Leygue E, Kemp A, Ung K, Vendetti M \& Shiu R 2005 Inducible upregulation of oestrogen receptor-betal affects oestrogen and tamoxifen responsiveness in MCF7 human breast cancer cells. Journal of Molecular Endocrinology 34 553-566.

Muschenheim F, Furst J \& Bates H 1978 Increased incidence of positive tests for estrogen binding in mammary carcinoma specimens transported in liquid nitrogen. American Journal of Clinical Pathology 70 780-782.

Myers E, Fleming F, Crotty T, Kelly G, McDermott E, O'Higgins N, Hill A \& Young L 2004 Inverse relationship between ER-beta and SRC-1 predicts outcome in endocrine resistant breast cancer. British Journal of Cancer 91 1687-1693.

Nakopoulou L, Panayotopoulou A.L, Giannopoulou I, Givalos N, Markaki S \& Keramopoulos A 2004 The favourable prognostic value of oestrogen receptor beta immunohistochemical expression in breast cancer. Journal of Clinical Pathology 57 523-528.

O’Neill P, Davies M, Shaaban A, Innes H, Torevell A, Sibson D \& Foster C 2004 Wild-type oestrogen receptor beta (ERbeta1) mRNA and protein expression in Tamoxifentreated post-menopausal breast cancers. British Journal of Cancer 91 1694-1702. 
Ogawa S, Inoue S, Watanabe T, Orimo A, Hosoi T, Ouchi Y \& Muramatsu M 1998 Molecular cloning and characterization of human estrogen receptor bcx: potential inhibitor of estrogen action in human. Nucleic Acids Research 26 3505-3512.

Omoto Y, Inoue S, Ogawa S, Toyama T, Yamashita H, Muramatsu M, Kobayashi S \& Iwase H 2001 Clinical value of the wild-type estrogen receptor beta expression in breast cancer. Cancer Letters 163 207-212.

Omoto Y, Kobayashi S, S Inoue S Ogawa S, Toyama T, Yamashita H, Muramatsu M, Gustafsson J \& Iwase H 2002 Evaluation of oestrogen receptor beta wild-type and variant protein expression and relationship with clinicopathological factors in breast cancers. European Journal of Cancer 38 380-386.

Osborne C 1998 Steroid hormone receptors in breast cancer management. Breast Cancer Research Treatment $51227-238$.

Peng B, Lu B, Leygue E \& Murphy L 2003 Putative functional characteristics of human estrogen receptor-beta isoforms. Journal of Molecular Endocrinology 30 13-29.

Roger P, Sahla M, Makela S, Gustafsson J.A, Baldet P \& Rochefort H 2001 Decreased expression of estrogen receptor beta protein in proliferative preinvasive mammary tumors. Cancer Research 61 2537-2541.

Saji S, Omoto Y, Shimizu C, Horiguchi S, Watanabe T, Funata N, Hayash S, Gustafsson J \& Toi M $2002 a$ Clinical impact of assay of estrogen receptor beta cx in breast cancer. Breast Cancer Research Treatment 9 303-307.

Saji S, Omoto Y, Shimizu C, Warner M, Hayashi Y, Horiguchi S, Watanabe T, Hayashi S \& Gustafsson J $2002 b$ Expression of estrogen receptor (ER) (beta)cx protein in ER(alpha)-positive breast cancer: specific correlation with progesterone receptor. Cancer Research $624849-4853$.
Saji S, Hirose M \& Toi M 2005 Clinical significance of estrogen receptor beta in breast cancer. Cancer Chemotherapy and Pharmacology 56 s21-s26.

Saunders A, Millar M, Williams K, Macpherson S, Bayne C, O’Sullivan C, Anderson T, Groome N \& Miller W 2002 Expression of oestrogen receptor beta $(\mathrm{ER} \beta 1)$ protein in human breast cancer biopsies. British Journal of Cancer $\mathbf{8 6}$ 250-256.

Shaaban A, Sloane J, West C, Moore F, Jarvis C, Williams E \& Foster C 2002 Histopathologic types of benign breast lesions and the risk of breast cancer. Case-control study. American Journal of Surgery and Pathology 26 421-430.

Skliris G, Parkes A, Limer J, Burdall S, Carder P \& Speirs V 2002 Evaluation of seven oestrogen receptor $b$ antibodies for immunohistochemistry western blotting and flow cytometry in human breast tissue. Journal of Pathology 197 155-162.

Skliris G, Munot K, Bell S, Carder P, Lane S, Horgan K, Lansdown M, Parkes A, Hanby A, Markham A \& Speirs V 2003 Reduced expression of oestrogen receptor beta in invasive breast cancer and its re-expression using DNA methyltransferase inhibitors in a cell line model. Journal of Pathology 201 213-220.

Skliris GP, Snell L, Watson PH \& Murphy LC 2005 Expression of ERB in ERA negative human breast cancers. In 96th AACR Annual General Meeting. Anaheim CA, USA. Vol. 96. pp. Abstract 2155.

Speirs V 2002 Oestrogen receptor beta in breast cancer: good bad or still too early to tell? Journal of Pathology 197 143-147.

Watson P, Snell L \& Parisien M 1996 The NCIC-Manitoba Breast Tumor Bank: a resource for applied cancer research. Canadian Medical Association Journal 155 281-283.

Weihua Z, Saji S, Makinen S, Cheng G, Jensen E, Warner M \& Gustaffson JA 2000 Estrogen receptor (ER) $\beta$ a modulator of ER $\alpha$ in the uterus. PNAS 97 5936-5941. 